\section{PENANGGULANGAN PENCEMARAN LINGKUNGAN LAUT MENURUT UNDANG- UNDANG NOMOR 32 TAHUN 2014 TENTANG KELAUTAN ${ }^{1}$ \\ Oleh: Jestika Erika Lambonan ${ }^{2}$}

\begin{abstract}
ABSTRAK
Penelitian ini dilakukan dengan tujuan untuk
\end{abstract} mengetahui bagaimana terjadinya pencemaran lingkungan laut di wilayah perairan Indonesia dan bagaimana penanggulangan pencemaran lingkungan laut menurut Undang-Undang Nomor 32 Tahun 2014 Tentang Kelautan. Dengan menggunakan metode peneltian yuridis normatif, disimpulkan: 1. Terjadinya pencemaran lingkungan laut di wilayah perairan Indonesia disebabkan oleh pencemaran yang berasal dari daratan, kegiatan di laut dan kegiatan dari udara. Pencemaran laut dapat terjadi: di wilayah perairan atau wilayah yurisdiksi atau dari luar wilayah perairan atau dari luar wilayah yurisdiksi Indonesia. Bencana Kelautan dapat terjadi disebabkan oleh pencemaran lingkungan; dan/atau pemanasan global. Proses penyelesaian sengketa dan penerapan sanksi pencemaran laut dilaksanakan berdasarkan prinsip pencemar membayar dan prinsip kehati-hatian. 2. Penanggulangan pencemaran lingkungan laut menurut UndangUndang Nomor 32 Tahun 2014 Tentang Kelautan dilaksanakan oleh pemerintah dengan menetapkan kebijakan penanggulangan dampak pencemaran laut dan bencana Kelautan melalui: pengembangan sistem mitigasi bencana dan pengembangan sistem peringatan dini (early warning system) serta pengembangan perencanaan nasional tanggap darurat tumpahan minyak di Laut dan pengembangan sistem pengendalian pencemaran Laut dan kerusakan ekosistem Laut termasuk pengendalian dampak sisa-sisa bangunan di Laut dan aktivitas di Laut.

Kata kunci: Penanggulangan, Pencemaran, Lingkungan Laut.

\footnotetext{
${ }^{1}$ Artikel Skripsi. Dosen Pembimbing: Dr. Ralfie Pinasang $\mathrm{SH}, \mathrm{MH}$; Michael G. Nainggolan, SH, MH, DEA

2 Mahasiswa pada Fakultas Hukum Unsrat, NIM. 16071101314
}

\section{PENDAHULUAN}

\section{A. Latar Belakang}

Menurut Penjelasan Atas Undang-Undang Nomor 32 Tahun 2014 Tentang Kelautan, Indonesia merupakan negara kepulauan terbesar di dunia dengan potensidan kekayaan alam yang berrimpah sebagai karunia Tuhan ying Maha Esa memiliki makna yang sangat penting bagi bangsa Indonesia sebagai ruang hidup (lebenstraum) dan ruang juang serta media pemersatu yang menghubungkan pulaupulau dalam satu kesatuan ideologi, politik, ekonomi, sosial, budaya, pertahanan, dan keamanan dalam suatu wadah ruang wilayah Negara Kesatuan Republik Indonesia.

Di dalam hukum internasional, terdapat berbagai macam konvensi yang mengatur mengenai perlindungan lingkungan laut dari sumber pencemaran yang berasal dari kapal, antara lain air balas, minyak, atau sampah selama pelayaran. United Nations on the Law of the Sea (UNCLOS) mengatur mengenai perlindungan lingkungan laut di dalam Bagian XII. Terdapat enam sumber pencemaran terhadap lingkungan laut yang diatur di UNCLOS, yaitu aktivitas di daerah pantai, kegiatan pengeboran minyak di landas kontinen, penambangan di daerah seabed, pembuangan limbah ke laut (dumping), pencemaran yang berasal dari kapal, dan pencemaran dari lapisan atmosfir. ${ }^{3}$

Menurut Penjelasan Atas Undang-Undang Nomor 32 Tahun 2009 tentang Perlindungan Dan Pengelolaan Lingkungan Hidup, UndangUndang Dasar Negara Republik Indonesia Tahun 1945 menyatakan bahwa lingkungan hidup yang baik dan sehat merupakan hak asasi dan hak konstitusional bagi setiap warga negara Indonesia. Oleh karena itu, negara, pemerintah, dan seluruh pemangku kepentingan berkewajiban untuk melakukan perlindungan dan pengelolaan lingkungan hidup dalam pelaksanaan pembangunan berkelanjutan agar lingkungan hidup Indonesia dapat tetap menjadi sumber dan penunjang hidup bagi rakyat Indonesia serta makhluk hidup lain.

\footnotetext{
${ }^{3}$ Eliza Dayinta Harumanti. Pengelolaan Air Balas: Kerangka Hukum Internasional Dan Perbandingan Hukum Di Indonesia. Indonesian Center for Environmental Law (Lembaga Pengembangan Lingkungan Indonesia) Jurnal Hukum Lingkungan Indonesia. Vol. 2 Issue 1, Juli 2015 hlm. 74.
} 
Undang-Undang Nomor 32 Tahun 2009 tentang Perlindungan Dan Pengelolaan Lingkungan Hidup. Pasal 1 angka 14. Pencemaran lingkungan hidup adalah masuk atau dimasukkannya makhluk hidup, zat, energi, dan/atau komponen lain ke dalam lingkungan hidup oleh kegiatan manusia sehingga melampaui baku mutu lingkungan hidup yang telah ditetapkan. Pasal 1 angka 16. Perusakan lingkungan hidup adalah tindakan orang yang menimbulkan perubahan langsung atau tidak langsung terhadap sifat fisik, kimia, dan/atau hayati lingkungan hidup sehingga melampaui kriteria baku kerusakan lingkungan hidup. Pasal 1 angka 17. Kerusakan lingkungan hidup adalah perubahan langsung dan/atau tidak langsung terhadap sifat fisik, kimia, dan/atau hayati lingkungan hidup yang melampaui kriteria baku kerusakan lingkungan hidup.

Apabila terjadi pencemaran lingkungan laut di wilayah perairan Indonesia, maka akan menimbulkan kerugian bagi bangsa dan negara, karena kualitas lingkungan hidup di laut akan menurun dan dapat mengancam kelangsungan makhluk hidup sehingga perlu dilakukan perlindungan dan pengelolaan lingkungan hidup melalui upaya penanggulangan terhadap pencemaran lingkungan laut.

\section{B. Rumusan Masalah}

1. Bagaimanakah terjadinya pencemaran lingkungan laut di wilayah perairan Indonesia?

2. Bagaimanakah penanggulangan pencemaran lingkungan laut menurut Undang-Undang Nomor 32 Tahun 2014 Tentang Kelautan ?

\section{Metode Penelitian}

Metode penelitian hukum normatif ialah metode penelitian yang digunakan untuk menyusun penulisan ini dan ditunjang dengan data-data sekunder yang diperoleh dari studi kepustakaan. Data sekunder merupakan kumpulan dari bahan-bahan hukum primer, sekunder dan tersier. Bahan hukum primer berupa peraturan perundang-undangan yang mengatur mengenai kelautan. Bahan hukum sekunder berupa literatur-literatur dan karyakarya ilmiah hukum dan bahan hukum tersier dan juga seperti kamus-kamus umum dan kamus-kamus hukum.

\section{PEMBAHASAN}

\section{A. Terjadinya Pencemaran Lingkungan Laut Di Wilayah Perairan Indonesia}

Peristiwa pencemaran laut kerap terjadi di Indonesia akibat tumpahan minyak, tabrakan kapal dengan terumbu karang, pembuangan air limbah yang mencemari laut, dan masih banyak lagi. Peristiwa tersebut antara lain: kasus montara yang sudah berlangsung selama 10 tahun, tumpahan minyak di Balikpapan yang terjadi tahun 2018, dan tabrakan Kapal MV Caledonia Sky dengan terumbu karang di Raja Ampat. Pencemaran-pencemaran tesebut tentu terdapat kerugian pencemaran dan/atau kerusakan ekosistem pesisir dan laut dan menjadi hal yang penting untuk menghitung kerugian pencemaraan tersebut. ${ }^{4}$

Kematian paus sperma di Wakatobi beberapa hari yang lalu menunjukan bahwa Indonesia darurat sampah plastik. Hal ini dikarenakan ditemukannya 5,9 kg sampah didalam perut paus sperma, ketika perut paus ini dibelah oleh warga di Desa Kapota Utara, Kecamatan Wangi-Wangi Selatan, Kabupaten Wakatobi, Sulawesi Tenggara. Januari 2016, kejadian yang sama juga pernah terjadi. Sebanyak 13 paus sperma mati di bibir pantai Jerman, didalam perut paus tersebut ditemukan gumpalan-gumpalan plastik yang mengisyaratkan bahwa dunia saat ini memiliki problem yang sama dalam pengelolaan sampah plastik.

Kematian paus sperma merupakan salah satu bahaya yang ditimbulkan oleh adanya sampah plastik di lautan. Dikutip dari laman beberapa media lokal, ada sekitar 260 spesies laut yang terdampak dari adanya sampah di laut, survei yang telah dilakukan di Universitas Hasanuddin Makassar, juga menyatakan bahwa 28 persen ikan yang ada di pasar ikan mengkonsumsi plastik. Hal ini tidak menutup kemungkinan biota laut lainnya akan tidak sengaja memakan sampah plastik juga, karena mengganggap plastik tersebut merupakan makanan mereka.

Penutupan permukaan laut oleh sampah plastik dapat membahayakan biota laut yang

4 https://icel.or.id/pencemaran-laut-dan-perhitungankerugiannya/ Diakses 8/19/2019: 5:51 Wita. 
memberikan manfaat sangat besar bagi jutaan penduduk yang hidup dekat pesisir ini. Padahal, terumbu karang membutuhkan cahaya matahari agar dapat bertahan hidup. ${ }^{5}$ Selain itu keberadaan partikel plastik kecil (microplastics) juga menjadi ancaman yang serius bagi kesehatan pangan yang berasal dari laut. Peneliti Pusat Penelitian Oseanografi (P2O) Lembaga Ilmu Pengetahuan Indonesia (LIPI) M Reza Cordova saat dikutip dari laman berita Mongabay menyatakan bahwa, microplastics yang ada di dalam air laut Indonesia diperkirakan berkisar 30 hingga 960 partikel/liter. ${ }^{6}$

Indonesia merupakan negara yang memiliki wilayah kepulauan yang terbesar di dunia. Indonesia memiliki 17.499 pulau dari Sabang hingga Merauke. Luas total wilayah Indonesia adalah 7,81 juta $\mathrm{km}^{2}$ yang terdiri dari 2,01 juta $\mathrm{km}^{2}$ daratan, 3,25 juta $\mathrm{km}^{2}$ lautan, dan 2,55 juta $\mathrm{km}^{2}$ Zona Ekonomi Eksklusif (ZEE). Dengan memiliki cakupan wilayah kepulauan yang besar, tentunya Indonesia memiliki sumber daya alam pesisir yang cukup besar karena didukung adanya ekosistem terumbu karang, padang lamun dan mangrove. Sumberdaya hayati laut pada kawasan pesisir Indonesia juga memiliki potensi keragaman dan nilai ekonomis yang tinggi salah satunya adalah ikan. Kita ketahui bahwa perikanan Indonesia mampu menjadi salah satu penompang pangan di Indonesia. Ketersediaan produksi ikan dapat menggantikan pangan dari budidaya holtikultura dan perternakan. Melansir berita dari Bisnis.com, produksi perikanan tangkap 2018 ditargetkan 9,45 juta ton setara Rp209,8 triliun setelah realisasi 2017 meleset dari target. Berdasarkan data estimasi Ditjen Perikanan Tangkap Kementerian Kelautan dan Perikanan (KKP), produksi perikanan tangkap tahun lalu 7,7 juta ton yang terdiri atas 7 ton ikan laut dan 642.670 ton ikan perairan darat. Volume itu setara Rp158 triliun. ${ }^{7}$

Undang-Undang Nomor 32 Tahun 2014 Tentang Kelautan. Pasal 52 ayat:

(1) Pencemaran Laut meliputi:

a. pencemaran yang berasal dari daratan;

5 https://icel.or.id/sayangi-laut-penanganan-sampahharus-dari-hulu/ Diakses 8/19/2019: 5:51 Wita.

${ }^{6}$ lbid.

7 https://icel.or.id/laut-yang-sehat-untuk-perikanan-diindonesia/ Diakses 8/19/2019: 5:51 Wita. b. pencemaran yang berasal dari kegiatan di Laut; dan

c. pencemaran yang berasal dari kegiatan dari udara.

(2) Pencemaran Laut sebagaimana dimaksud pada ayat (I) dapat terjadi:
a. di wilayah perairan atau wilayah yurisdiksi;
b. dari luar wilayah perairan atau dari luar wilayah yurisdiksi; atau
c. dari dalam wilayah perairan atau wilayah yurisdiksi ke luar wilayah yurisdiksi Indonesia.

(3) Proses penyelesaian sengketa dan penerapan sanksi Pencemaran Laut sebagaimana dimaksud pada ayat (1) dan ayat (2) dilaksanakan berdasarkan prinsip pencemar membayar dan prinsip kehatihatian

(4) Ketentuan lebih lanjut mengenai proses penyelesaian dan sanksi terhadap Pencemaran Laut dilaksanakan sesuai dengan ketentuan peraturan perundangundangan.

\section{B. Penanggulangan Pencemaran Lingkungan Laut Menurut Undang-Undang Nomor 32 Tahun 2014 Tentang Kelautan}

Penanggulangan pencemaran laut dapat dilakukan dengan cara sebagai berikut :

1. Melakukan proses bioremediasi, diantaranya melepaskan serangga untu menetralisir pencemaran laut yang disebabkan oleh tumpahan minyak dari ledakan ladang minyak.

2. Fitoremediasi dengan menggunakan tumbuhan yang mampu menyerap logam berat juga ditempuh. Salah satu tumbuhan yang digunakan tersebut adalah pohon apiapi (Avicennia marina). Pohon Api-api memiliki kemampuan akumulasi logam berat yang tinggi.

3. Melakukan pembersihan laut secara berkala dengan melibatkan peran serta masyarakat. ${ }^{8}$ Usaha yang dapat dilakukan untuk mencegah dan mengurangi tingkat pencemaran laut diantaranya adalah :

8 https://www.dictio.id/t/bagaimana-carapenanggulangan-pencemaran-laut/110005. Diakses 8/14/ 2019 5:47 Wita. 
1. Meningkatkan kesadaran masyarakat akan pentingnya laut bagi kehidupan.

2. Menggalakkan kampanye untuk senantiasa menjaga dan melestarikan laut beserta isinya.

3. Tidak membuang sampah ke sungai yang bermuara ke laut.

4. Tidak menggunakan bahan-bahan berbahaya seperti bom, racun, pukat harimau, dan lain-lain yang mengakibatkan rusaknya ekosistem laut.

5. Tidak menjadikan laut sebagai tempat pembuangan limbah produksi pabrik yang akan mencemari laut. ${ }^{9}$

Undang-Undang Nomor 32 Tahun 2014

Tentang Kelautan. Pasal 54 ayat:

(1) Dalam mengantisipasi Pencemaran Laut dan bencana Kelautan sebagaimana dimaksud dalam Pasal 52 dan Pasal 53, Pemerintah menetapkan kebijakan penanggulangan dampak Pencemaran Laut dan bencana Kelautan.

(2) Kebijakan penanggulangan dampak pencemaran dan bencana Kelautan sebagaimana dimaksud pada (1) dapat dilakukan melalui:

a. pengembangan sistem mitigasi bencana;

b. pengembangan sistem peringatan dini (early warning system);

c. pengembangan perencanaan nasional tanggap darurat tumpahan minyak di Laut;

d. pengembangan sistem pengendalian pencemaran Laut dan kerusakan ekosistem Laut; dan

e. pengendalian dampak sisa-sisa bangunan di Laut dan aktivitas di Laut.

Pasal 55 ayat:

(1) Pemerintah dan menyelenggarakan Pemerintah Daerah wajib sistem pencegahan dan Daerah penanggulangan pencemaran dan kerusakan lingkungan Laut.

(2) Pemerintah dan Pemerintah wajib menyelenggarakan sistem pencegahan dan penanggulangan bencana Kelautan sebagai bagian yang terintegrasi dengan sistem pencegahan dan penanggulangan bencana nasional.

\footnotetext{
9 Ibid.
}

Pasal 56 ayat:

(1) Pemerintah bertanggung jawab dalam melindungi dan melestarikan lingkungan Laut.

(2) Pelindungan dan pelestarian lingkungan Laut sebagaimana dimaksud pada ayat (1) dilakukan melalui pencegahan, pengurangan, dan pengendalian lingkungan Laut dari setiap Pencemaran Laut serta penanganan kerusakan lingkungan Laut.

(3) Pemerintah bekerja sama, baik bilateral, regional, maupun multilateral dalam melaksanakan pencegahan, pengurangan, dan pengendalian sebagaimana dimaksud pada ayat (2).

Pasal 57. Pelindungan dan pelestarian lingkungan Laut sebagaimana dimaksud dalam Pasal 56 dilaksanakan berdasarkan ketentuan peraturan perundang-undangan dan hukum laut internasional.

Sabtu 31 Maret 2018, langit dan air di Teluk Balikpapan, Kalimantan Timur, berwarna hitam. Langit hitam karena kapal terbakar, di laut terjadi tumpahan minyak mentah. Saat itu, diduga tumpahan karena kegiatan salah satu perusahaan eksploitasi minyak belakangan terungkap, kalau tumpahan minyak karena pipa bawah laut PT Pertamina, terputus. Minyak mentah pun tumpah mengotori laut. Informasi resmi mengenai kronologis peristiwa ini -termasuk siapa pihak bertanggungjawab tidak disampaikan segera kepada publik, terlebih dahulu beredar informasi tak resmi mengenai dampak tumpahan minyak yang menguraikan ada korban jiwa, kerugian lingkungan dan kerugian masyarakat. ${ }^{10}$

Kalau mengacu Pasal 53, ayat 2 huruf (a) Undang-undang Nomor 32 Tahun 2009 (selanjutnya disebut UU 32/2009), pemberian informasi kepada masyarakat merupakan salah satu langkah dalam upaya penanggulangan. Selain penyampaian informasi resmi cepat dan tepat, setidaknya ada tiga langkah lain perlu dilakukan pemerintah dalam menangani kasus ini. Pertama, memastikan pihak bertanggungjawab melakukan penanggulangan atau jika belum dapat ditentukan, pemerintah terlebih dahulu melakukan penanggulangan. Kedua, memastikan pihak yang

\footnotetext{
10 Raynaldo Sembiring, Penanggulangan dan Langkah Hukum pada Kasus Tumpahan Minyak di Teluk Balikpapan (Opini). https://www.mongabay.co.id/category/opini/ Diakses 8/14/2019: 5:51 Wita.
} 
bertanggungjawab untuk pemulihan lingkungan. Ketiga, upaya penegakan hukum yang bersifat melengkapi kedua poin sebelumnya. Kedua langkah pertama merupakan prioritas pertama, sedangkan langkah terakhir sebagai prioritas kedua. ${ }^{11}$

Pembicaraan publik di media sosial dan pemberitaan media massa awal terjadi peristiwa tidak fokus kepada upaya "penanggulangan keadaan darurat." Banyak pernyataan mengenai perlu valuasi kerugian lingkungan atau penegakan hukum, tentunya, kedua hal ini tidak salah, namun dalam keadaan seperti ini, pembicaraan dan tindakan penanggulangan seharusnya lebih diutamakan. Basis regulasi mengenai penanggulangan karena tumpahan minyak di laut telah diatur lebih lengkap dalam Peraturan Presiden Nomor 109 Tahun 2006 tentang Penanggulangan Keadaan Darurat Tumpahan Minyak Di Laut. Perpres ini disusun agar pemerintah dapat melakukan tindakan secara cepat, tepat dan terkoordinasi untuk mencegah, mengatasi, menanggulangi dan meminimalisir dampak akibat penyebaran tumpahan minyak di laut. Hal menarik dari Perpres 109/2006 adalah kewajiban nakhoda atau pimpinan, pemilik, operator kapal, penanggung jawab unit pengusahaan minyak lepas pantai, pimpinan unit pengusahaan migas atau pimpinan atau penanggung jawab kegiatan lain untuk penanggulangan dalam keadaan darurat.

Hal ini merupakan pengejawantahan dari prinsip pencemar membayar (polluter pays principle), yang diperkuat dengan pengaturan Pasal 11 mengenai tanggung jawab mutlak (strict liability) atas biaya penanggulangan, kerugian masyarakat dan kerusakan lingkungan. Dengan pengaturan itu, perpres ini meminimalisir penggunaan APBN dalam penanggulangan keadaan darurat. Penanggulangan dalam keadaan darurat merupakan kewajiban pencemar, sehingga penanggungjawab usaha otomatis bertanggungjawab tanpa perlu membuktikan unsur kesalahan.

Ketika, dapat dipastikan siapa pihak bertanggungjawab dan demi mencegah dampak lingkungan lebih luas, pemerintah

${ }^{11}$ Ibid. dapat melakukan penanggulangan terlebih dahulu. Biaya yang timbul dari kegiatan penanggulangan ini akan dibebankan kepada pencemar. Jika pencemar telah melakukan penanggulangan, penting bagi pemerintah untuk mengawasi apakah penanggulangan (clean up) itu sudah benar-benar bersih. Yang perlu dipahami, bersih tidak bersihnya laut akibat tumpahan minyak bukan ditentukan oleh pencemar, melainkan pemerintah dengan dukungan ahli. ${ }^{12}$

Keterlibatan masyarakat (community participation) dalam proses pembangunan dianggap penting dalam upaya untuk menghasilkan kebijakan yang efektif dan dapat dirasakan manfaatnya oleh masyarakat sebagai pihak penerima manfaat pembangunan. Konsep ini juga dipercaya dapat meminimalkan dampak negatif dari pembangunan. Selain itu, partisipasi masyarakat juga memberi kesempatan kepada masyarakat untuk memperoleh informasi yang berimbang dan obyektif, yang berkontribusi untuk pemecahan masalah dan meminimalkan konflik dalam pembangunan khususnya pembangunan masyarakat di wilayah pesisir. ${ }^{13}$

Program pengelolaan pesisir berbasis masyarakat mengembangkan pengelolaan bersama antara pemerintah kabupaten/kota dan masyarakat. Program ini menempatkan masyarakat sebagai aktor utama dalam pelaksanaan program, dengan dukungan pemerintah kabupaten/kota. Pengembangan konsep ini dapat menjadi salah satu jawaban dalam upaya menerapkan tata kelola pemerintahan yang baik, yang tidak hanya menggambarkan demokrasi dalam pengambilan keputusan tetapi juga menggambarkan sistem jaringan antara pemerintah dan masyarakat. Sistem jaringan yang diharapkan menjadi proses penting untuk mengatasi kompleksitas dan tantangan yang dihadapi dalam upaya perlindungan dan pengelolaan lingkungan untuk mewujudkan pembangunan berkelanjutan. ${ }^{14}$

\footnotetext{
12 Ibid.

13 Safrina. Partisipasi Masyarakat Dalam Pengelolaan Wilayah Pesisir Di Aceh. Indonesian Center for Environmental Law (Lembaga Pengembangan Lingkungan Indonesia) Jurnal Hukum Lingkungan Indonesia. Vol. 2 Issue 1, Juli 2015.hlm. 46.

14 Ibid. hlm. 46.
} 
Menurut Penjelasan Atas Peraturan Pemerintah Republik Indonesia Nomor 19 Tahun 1999 Tentang Pengendalian Pencemaran Dan/Atau Perusakan Laut, angka (1) Pencemaran laut diartikan dengan masuknya atau dimasukannya makhluk hidup, zat, energi, dan/atau komponen lain ke dalam lingkungan laut oleh kegiatan manusia sehingga kualitasnya turun sampai ke tingkat tertentu yang menyebabkan lingkungan laut tidak sesuai lagi dengan baku mutu dan/atau fungsinya. Hal ini berarti, bahwa perlu ditetapkan baku mutu air laut yang berfungsi sebagai tolok ukur untuk menentukan telah terjadinya pencemaran laut. Selain itu juga sangat berguna bagi penentuan status mutu laut. Karena sangat erat kaitannya antara tingkat pencemaran laut dengan status mutu laut itu sendiri. Angka (2) Perusakan laut adalah tindakan yang menimbulkan perubahan langsung dan/atau tidak langsung terhadap sifat fisik dan/atau hayatinya yang melampaui kriteria baku kerusakan laut. Hal ini berarti bahwa perlu ditetapkan kriteria baku kerusakan laut yang berfungsi sebagai tolok ukur untuk menentukan tingkat kerusakan laut. Selain itu juga sangat berguna bagi penentuan status mutu laut. Karena sangat erat kaitannya antara tingkat kerusakan laut dengan status mutu laut itu sendiri. ${ }^{15}$

Pengendalian Pencemaran dan/atau perusakan laut merupakan kegiatan yang mencakup :

1. Inventarisasi kualitas laut dilakukan dengan mempertimbangkan berbagai kriteria yang ada dalam pengendalian pencemaran dan/atau perusakan laut.

2. Penetapan baku mutu air laut dan kriteria baku kerusakan laut yang digunakan sebagai tolok ukur utama pengendalian pencemaran dan/atau perusakan laut.

3. Pemantauan kualitas air laut dan pengukuran tingkat kerusakan laut yang diikuti dengan pengumpulan hasil pemantauan yang dilakukan oleh instansi lain, evaluasi dan analisis terhadap hasil yang diperoleh serta pembuatan laporan.

4. Penetapan status mutu laut di suatu daerah.

5. Perencanaan dan pelaksanaan kebijakan pengendaliannya untuk mempertahankan

15 Penjelasan Atas Peraturan Pemerintah Republik Indonesia Nomor 19 Tahun 1999 Tentang Pengendalian Pencemaran Dan/Atau Perusakan Laut. mutu laut agar tetap baik atau memperbaiki mutu laut yang telah tercemar atau rusak.

6. Pengawasan terhadap penaatan peraturan pengendalian pencemaran dan/atau perusakan laut termasuk penaataan mutu limbah yang dibuang ke laut dan/atau penaataan terhadap kriteria baku kerusakan laut serta penindakan, pemulihan dan penegakan hukumnya. ${ }^{16}$

Indonesia merupakan negara kepulauan terbesar di dunia dengan luas lautanya sebesar 75\% dari luas daratannya atau sekitar 6 juta $\mathrm{Km}^{2}$, Indonesia juga mempunyai garis pantai sepanjang lebih kurang $81.000 \mathrm{Km}$ dan merupakan garis pantai terpanjang kedua di dunia. Berdasarkan Konvensi Hukum Laut 1982 (UNCLOS 1982), Indonesia mempunyai kedaulatan atas wilayah perairan seluas 3,2 $\mathrm{Km}^{2}$ yang terdiri dari Perairan Kepulauan seluas 2,9 juta $\mathrm{Km}^{2}$ dan laut Teritorial seluas 0,3 juta $\mathrm{Km}^{2}$. Selain itu, wilayah laut kita memiliki potensi sumberdaya alam yang luar biasa yang sampai saat ini belum dikelola secara optimal. Kita juga mempunyai hak berdaulat atas sumberdaya alam laut tersebut dan berbagai kepentingan yang terkait pada perairan ZEE seluas 2.7 juta $\mathrm{Km}^{2} 17$

Peraturan Pemerintah Republik Indonesia Nomor 19 Tahun 1999 Tentang Pengendalian Pencemaran Dan/Atau Perusakan Laut, mengatur mengenai Pengawasan, sebagaimana dinyatakan pada Pasal 19 ayat:

(1) Menteri melakukan pengawasan terhadap penaatan penanggung jawab usaha dan/atau kegiatan yang dapat menyebabkan terjadinya pencemaran dan/atau perusakan laut.

(2) Untuk melakukan pengawasan sebagaimana dimaksud pada ayat (1), Menteri dapat menetapkan pejabat yang berwenang melakukan pengawasan.

Pasal 20 ayat:

(1) Untuk melaksanakan tugasnya, pengawas sebagaimana dimaksud dalam Pasal 19 berwenang melakukan pemantauan, meminta keterangan, membuat salinan dari

16 Penjelasan Atas Peraturan Pemerintah Republik Indonesia Nomor 19 Tahun 1999 Tentang Pengendalian Pencemaran Dan/Atau Perusakan Laut.

${ }^{17}$ Etty R. Agoes, (Penyunting) Dimanahkah Batas-Batas Wilayah Kita Di Laut ?, Departemen Kelautan dan Perikanan, Jakarta, 13 Desember 2000, hal. 1. 
dokumen dan/atau membuat catatan yang diperlukan, memasuki tempat tertentu, mengambil contoh, memeriksa peralatan, memeriksa instalasi dan/atau alat transportasi, serta meminta keterangan dari pihak yang bertanggung jawab atas usaha dan/atau kegiatan.

(2) Penanggung jawab usaha dan/atau kegiatan yang dimintai keterangan sebagaimana dimaksud pada ayat (1), wajib memenuhi permintaan petugas pengawas sesuai dengan ketentuan peraturan perundang-undangan yang berlaku.

(3) Setiap pengawas wajib memperlihatkan surat tugas dan/atau tanda pengenal serta wajib memperhatikan situasi dan kondisi tempat pengawasan tersebut.

Pasal 21. Setiap penanggung jawab usaha dan/atau kegiatan, wajib :

a. mengizinkan pengawas memasuki lingkungan kerjanya dan membantu terlaksananya tugas pengawasan tersebut;

b. memberikan keterangan dengan benar, baik secara lisan maupun tertulis apabila hal itu diminta pengawas;

c. memberikan dokumen dan/atau data yang diperlukan oleh pengawas;

d. mengizinkan pengawas untuk melakukan pengambilan contoh limbah atau barang lainnya yang diperlukan pengawas; dan

e. mengizinkan pengawas untuk melakukan pengambilan gambar dan/atau melakukan pemotretan di lokasi kerjanya.

Pasal 22 'ayat:

(1) Setiap orang atau penanggung jawab usaha dan/atau kegiatan wajib menyampaikan laporan hasil pemantauan pengendalian pencemaran dan/atau perusakan laut yang telah dilakukan kepada instansi yang bertanggung jawab, instansi teknis dan instansi terkait lainnya.

(2) Pedoman dan tata cara pelaporan sebagaimana dimaksud pada ayat (1) ditetapkan lebih lanjut oleh Kepala instansi yang bertanggung jawab.

\section{PENUTUP}

\section{A. Kesimpulan}

1. Terjadinya pencemaran lingkungan laut di wilayah perairan Indonesia disebabkan oleh pencemaran yang berasal dari daratan, kegiatan di laut dan kegiatan dari udara. Pencemaran laut dapat terjadi: di wilayah perairan atau wilayah yurisdiksi atau dari luar wilayah perairan atau dari luar wilayah yurisdiksi Indonesia. Bencana Kelautan dapat terjadi disebabkan oleh pencemaran lingkungan; dan/atau pemanasan global. Proses penyelesaian sengketa dan penerapan sanksi pencemaran laut dilaksanakan berdasarkan prinsip pencemar membayar dan prinsip kehatihatian

2. Penanggulangan pencemaran lingkungan laut menurut Undang-Undang Nomor 32 Tahun 2014 Tentang Kelautan dilaksanakan oleh pemerintah dengan menetapkan kebijakan penanggulangan dampak pencemaran laut dan bencana Kelautan melalui: pengembangan sistem mitigasi bencana dan pengembangan sistem peringatan dini (early warning system) serta pengembangan perencanaan nasional tanggap darurat tumpahan minyak di Laut dan pengembangan sistem pengendalian pencemaran Laut dan kerusakan ekosistem Laut termasuk pengendalian dampak sisa-sisa bangunan di Laut dan aktivitas di Laut.

\section{B. Saran}

1. Untuk mencegah terjadinya pencemaran lingkungan laut di wilayah perairan Indonesia, maka pemerintah perlu melakukan upaya pelindungan lingkungan laut melalui: konservasi laut, pengendalian pencemaran laut, penanggulangan bencana Kelautan dan pencegahan dan penanggulangan kerusakan akibat bencana.

2. Penanggulangan pencemaran lingkungan laut wajib dilaksanakan oleh pemerintah dan pemerintah daerah melalui penerapan sistem pencegahan dan penanggulangan pencemaran dan kerusakan lingkungan Laut. Sistem pencegahan dan penanggulangan bencana kelautan sebagai bagian yang terintegrasi dengan sistem pencegahan dan penanggulangan bencana nasional. Pemerintah dapat bekerja sama, baik bilateral, regional, maupun multilateral 
dalam melaksanakan penanggulangan pencemaran dan kerusakan lingkungan laut dan bencana kelautan.

\section{DAFTAR PUSTAKA}

Agoes R Etty., (Penyunting) Dimanahkah BatasBatas Wilayah Kita Di Laut ?, Departemen Kelautan dan Perikanan, Jakarta, 13 Desember 2000.

Harumanti Dayinta Eliza. Pengelolaan Air Balas: Kerangka Hukum Internasional Dan Perbandingan Hukum Di Indonesia. Indonesian Center for Environmental Law (Lembaga Pengembangan Lingkungan Indonesia) Jurnal Hukum Lingkungan Indonesia. Vol. 2 Issue 1, Juli 2015.

Indonesian Center for Environmental Law (Lembaga Pengembangan Lingkungan Indonesia) Jurnal Hukum Lingkungan Indonesia. Vol. 2 Issue 1, Juli 2015 Mengembalikan Kejayaan Maritim Indonesia Berlandaskan Prinsip Pembangunan Berkelanjutan.

Hadiwinata? Marthin Ahmad. Analisis Hukum Terhadap Pengaturan Pengelolaan Perikanan Berbasis Masyarakat Di Indonesia. Indonesian Center for Environmental Law (Lembaga Pengemba/ngan Lingkungan Indonesia) Jurnal Hukum Lingkungan Indonesia. Vol. 2 Issue 1, Juli 2015.

H. Suratman dan Philips Dillah, Metode Penelitian Hukum, Alfabeta, Bandung, 2012.

Husni Lalu, Pengantar Hukum Ketenagakerjaan Indonesia, Edisi Revisi, PT. RajaGrafindo, Jakarta, 2008.

Nuh Muhammad. Etika Profesi Hukum. CV. Pustaka Setia. Bandung. 2011.

Nursadi Harsanto. Laporan Akhir Tim Pengkajian Hukum Tentang Implementasi Prinsip Pencemar Membayar Menurut Undang-Undang Nomor 32 Tahun 2014 Tentang Kelautan. Pusat Penelitian dan Pengembangan Sistem Hukum Nasional Badan Pembinaan Hukum Nasional Kementerian Hukum Dan Ham RI Jakarta, 2015.

Safrina. Partisipasi Masyarakat Dalam Pengelolaan Wilayah Pesisir Di Aceh.
Indonesian Center for Environmental Law (Lembaga Pengembangan Lingkungan Indonesia) Jurnal Hukum Lingkungan Indonesia. Vol. 2 Issue 1, Juli 2015.

Soekanto Soerjono, Pengantar Penelitian Hukum, UI Press, Jakarta, 2005.

Soekanto Soerjono dan Sri Mamudji, Penelitian Hukum Normatif Suatu Tinjauan Singkat, PT Raja Grafindo Persada, Jakarta. 1995.

Sudarsono, Pengantar IImu Hukum, Cetakan Kelima, PT. Rineka Cipta, Jakarta, 2007.

Supramono Gatot, Hukum Acara Pidana \& Hukum Pidana Di Bidang Perikanan, Rineka Cipta, Jakarta, 2011.

Supriadi dan Alimudin, Hukum Perikanan Indonesia, Cetakan Pertama, Sinar Grafika, Jakarta, 2011.

Thontowi Jawahir dan Pranoto Iskandar, Hukum Internasional Kontemporer, PT. Refika Aditama, Bandung, 2006

Tutik Triwulan Titik, Pengantar Hukum Perdata di Indonesia, Cetakan Pertama, Jakarta, 2006.

Usman, Aspek-Aspek Hukum Perbankan di Indonesia. Penerbit Gramedia Pustaka Utama. Jakarta. 2001.

Muhamad Abdulkadir, Hukum dan Penelitian Hukum, PT. Citra Aditya Bakti, Bandung. 2004.

\section{Peraturan Perundang-Undangan}

Undang-Undang Nomor 32 Tahun 2014

Tentang Kelautan.

Undang-Undang Nomor 32 Tahun 2009 tentang

Perlindungan Dan Pengelolaan Lingkungan

Hidup

Peraturan Pemerintah Republik Indonesia Nomor 19 Tahun 1999 Tentang Pengendalian Pencemaran Dan/Atau Perusakan Laut.

\section{Internet}

https://www.dictio.id/t/bagaimana-carapenanggulangan-pencemaran-laut/110005.

Diakses 8/14/ 2019 5:47 Wita.

Raynaldo Sembiring, Penanggulangan dan Langkah Hukum pada Kasus Tumpahan Minyak di Teluk Balikpapan (Opini). https://www.mongabay.co.id/category/opini/ Diakses 8/14/2019: 5:51 Wita. 
https://icel.or.id/pencemaran-laut-danperhitungan-kerugiannya/ Diakses 8/19/2019:

5:51 Wita.

https://icel.or.id/sayangi-laut-penanganansampah-harus-dari-hulu/ Diakses 8/19/2019: 5:51 Wita.

https://icel.or.id/laut-yang-sehat-untukperikanan-di-indonesia/Diakses8/19/2019:5:51 Wita.

https://www.dictio.id/t/bagaimana-carapenanggulangan-pencemaran-laut/110005. Diakses 8/14/ 2019 5:47 Wita.

https://www.slideshare.net/432414005/18507 1809-makalahpencemaranlaut. Pencemaran laut dan upaya penegakan hukumnya di indonesia. Diakses 8/19/2019: 6:08 Wita. 